\title{
Adolescents' and Parents' Perceptions About Core Values to Individual and Family Life: A Cross- Sectional Study Involving Seven European Countries
}

\author{
Cristina C. Vieira, PhD \\ Sciences of Education. Associate Professor. Faculty of Psychology and \\ Sciences of Education, University of Coimbra, Portugal \\ Luís Gonçalves \\ Portugal \\ Anja Jochl \\ Austria \\ Marianne Van Essche \\ Belgium \\ Athanasios Stavrianos \\ Greece \\ Laura Brie \\ Romania \\ Matija Pustovrh \\ Slovenia \\ Ayfer Summermatter \\ Turkey \\ With the collaboration of: \\ Harald Seeber, Elisabeth Brueggl, Aziza Majri, Diane Licoppe, Christos \\ Kolozof, Cristina Costa, Isabel Cristina Borges, Isabel Pratas, Laura \\ Cruceat, Jana Mlakar, Köksal Sezgin
}

doi: 10.19044/ejes.v3no4a27 URL:http://dx.doi.org/10.19044/ejes.v3no4a27

\begin{abstract}
Family, community and school are privileged contexts to acquire and consolidate fundamental values for governing individual life and interpersonal relations across lifespan, and such learning is more effective if there is congruence in the messages learned, and if children and adolescents are stimulated to develop critical thinking competences to deal with information. Involving a convenience sample of 889 subjects, 446 adolescents and 443 parents from seven European countries to whom a selfadministered questionnaire was applied, this paper presents the main results
\end{abstract}


of cross-comparisons between and within countries about the perceived importance of values for family. Participants were also asked to do a selfevaluation of themselves as models of citizenship for others. Overall, mothers tend to consider that values are more promoted in families than fathers, but there are no differences in the opinions of adolescent boys and girls. When males and females are compared with no distinction of generations, the latter agreed more with the significance of values for the family than the former. There are some specific differences between and within countries and sample groups in the evaluation of values and selfperceptions of citizenship performance. Despite the limited number of participants in each country, the discussion of results highlights the importance of debating the values that guide personal and societal principles inside and outside the family, in an effort to construct a world free of prejudice and discrimination and where every person, regardless of cultural, religious or ethnical identities, is invited to contribute to the common wellbeing.

Keywords: Family values; critical thinking; personal and cultural diversity; citizenship

\section{Introduction}

Learning to be a member of society and to participate in community life as a citizen with rights and responsibilities is not an easy task and families usually have the main role in teaching their youngsters about the core values that each person must follow and promote in the course of growing older. Empirical research about family dynamics has already shown that the best predictor of children's ideas is their parents' ideas (Goodnow \& Collins, 1990).

The challenges that parents face are also extended to other educational entities, such as schools and teachers, but the power of the messages learnt in the family context tend to have an impact on children's development and actions because of several factors (see Vieira, 2013): family can be considered a protected environment for learning; the strength of ties between family members tends to make role models more significant; learning tends to be more effective when behaviours observed by youngsters correspond to verbal clues from those figures that are emotionally important to them; children are very good observers of those who surround them, and the process of learning through observation begins very early in life, even before they are able to speak about what they see or think.

According to Rokeach (1973), a "value is an enduring belief that a specific mode of condute or end-state of existence is personally or socially preferable to an opposite or converse mode of conduct or end-state of 
existence” (p. 5). For the same author, "a value system is an enduring organization of beliefs concerning preferable modes of conduct or end-states of existence along a continuum of relative importance" (idem). In this sense, values are not only related to principles of behaviour but also to general goals of life, and because of that they transcend specific situations (Braithwaite \& Law, 1985). Values are therefore organizers that guide people's behaviour and result from personal decisions based on information, experience and available models.

In the process of apprehending, understanding and choosing core values for governing individual attitudes and decisions as well as those related to interpersonal, family and community life, each person learns and uses the information considered emotionally more significant. Thus, the course of becoming a citizen is influenced by inside and outside family models, by opportunities for experimenting with behaviours and discussing and contrasting opinions and by the development of an internal sense of being able to decide what is right or wrong. Such ability requires knowledge, but also coherence between what is deliberately taught and effectively performed. It also requires increasing critical thinking that normally becomes more complex with age, mainly during childhood and adolescence (Sprinthall \& Collins, 1994).

It is consensual that families can be seen as dynamic and interactive systems, where parents' modes of action influence sons and daughters and on a reciprocal basis children's and adolescents' conceptions and behaviours influence parents (Jacklin \& Reynolds, 1993). Furthermore, we agree that family is "one of the few social groups where members grow together, and where roles relating to power, control, capabilities and authority change over time" (McGillicuddy-De Lisi \& Sigel, 1995, p. 353). For this reason, the ideas about the world, goals for life and values advocated by parents and youngsters could be understood as the result of a mutual building process and a negotiation between both parts, sometimes with conflict, these processes culminating in the appearance of shared knowledge (Bugental \& Johnston, 2000).

Family life is regulated by such a type of knowledge even though the members aren't aware of it. The effects of shared ideas could be transformed into positive civic and social competences in parents and youngsters, but it could happen that family values constitute an obstacle to the healthy individual development of each member. In fact, the old and new problems of contemporary times may represent challenges to families they may not be prepared to face and answer properly, so the development of a partnership effort between families, schools, and communities is crucial in order to promote the acquisition and consolidation of positive mutual values (European Commission, 2016).The goal of all efforts to promote the 
acquisition and use of values is not to teach young girls and boys "what to think, but rather how to think, in order to navigate a world where not everyone holds their views, but we each have a duty to uphold the democratic principles which allow all cultures to co-exist” (Jagland, 2016, p. 7 ). The process of learning values requires time, knowledge and active practices in different contexts, and youngsters and adults "need the opportunity to examine value dilemma questions both to understand the issues involved and to grow from the experience" (Sprinthall \& Collins, 1994, p. 221).

Families, schools and communities have the supreme task of helping the development of "responsible, autonomous and solidary people that know and exercise their rights and duties through dialogue and respect for others, with a democratic, pluralist, critical thinking and creative spirit” (DGE, 2013, p. 1). For such a task of equipping citizens with tools for living together to be effective, it is also crucial to "adopt measures to tackle inequalities and structural disadvantages” (European Council, 2016, p. 18). This is also a common responsibility, at a local, nationwide and transnational level, also involving political decision makers, because problems of exclusion, privation, discrimination and oppression, among others, surely contribute to a distortion of people's values and to societal conflicts like those that we are living through currently.

\section{Methodology}

The study presented in this article was conducted during the second year of the Erasmus+ Project "Family, Community and School: the troika of my values" (2014-1-PT01-KA201-001041), financed by the European Union, with data being collected at the same time in the seven countries, ensuring the equivalence as much as possible of all the variables with potential impact on the results. The partners of the project were schools with the secondary level of education from Austria, Belgium, Greece, Portugal, Romania, Slovenia and Turkey. It was a quantitative cross-sectional study, and more specifically a survey that involved samples of students and their parents, and the main goals were to compare, within countries, the degree of agreement between parents and adolescents about some core values to family life and to learning citizenship in a family context, and to do comparisons between countries about the same perceptions both in youngsters and in their parents' generation.

\section{Participants}

The convenience sample of the study was composed by 889 subjects, 446 of them (50.2\%; $47.5 \%$ boys and $52.5 \%$ girls) adolescents and 443 (49.8\%; $29.1 \%$ fathers and $70.9 \%$ mothers) parents (see Table 1). The 
presence of adolescents of both sexes is balanced in the sample, but more than two thirds of the parents group was composed by mothers. The mean age of the adolescents was 15.77 years old, ranging from 13 to 22 ( $\mathrm{SD}=1.233)$; for parents, the mean age was 44.70 years old, ranging from 32 to $66(\mathrm{SD}=5.279)$.

Table 1. Distribution of the participants by 'family membership', age and sex

\begin{tabular}{|c|c|c|c|c|c|c|}
\hline \multirow{2}{*}{$\begin{array}{l}\text { Family } \\
\text { membership }\end{array}$} & \multirow{2}{*}{$n$} & \multirow{2}{*}{$\%$} & \multirow{2}{*}{$\begin{array}{l}\text { mean } \\
\text { (age) }\end{array}$} & \multirow[t]{2}{*}{$S D$ (age) } & \multicolumn{2}{|c|}{$\operatorname{Sex}(\%)^{(1)}$} \\
\hline & & & & & Males & Females \\
\hline Adolescents & 446 & 50.2 & 15.77 & 1.233 & 47.5 & 52.5 \\
\hline Parents & 443 & 49.8 & 44.70 & 5.279 & 29.1 & 70.9 \\
\hline Total & 889 & 100.0 & ---- & ---- & --- & --- \\
\hline
\end{tabular}

(1)These are relative percentages for each group of adolescents and of parents.

In table 2 it is possible to see the distribution of participants by country, which the research team had previously decided to be very equivalent in order to legitimize valid statistical cross comparisons of answers.

Table 2. Distribution of participants by country

\begin{tabular}{|l|l|l|}
\hline Country & $\begin{array}{l}\mathbf{n} \\
\text { (total sample; adolescents; parents; })\end{array}$ & $\mathbf{\%}$ \\
\hline Austria & $\begin{array}{l}130 \\
\text { (70 adolescents; } 60 \text { parents) }\end{array}$ & $\begin{array}{l}14.6 \\
(53.8 ; 46.2)\end{array}$ \\
\hline Belgium & 120 & 13.5 \\
& (60 adolescents; 60 parents) & $(50.0 ; 50.0)$ \\
\hline Greece & 104 & 11.7 \\
& (52 adolescents; 52 parents) & $(50.0 ; 50.0)$ \\
\hline Portugal & 118 & 13.3 \\
& (55 adolescents; 63 parents) & $(46.6 ; 53.4)$ \\
\hline Romania & 138 & 15.5 \\
& $(69$ adolescents; 69 parents) & $(50.0 ; 50.0)$ \\
\hline Slovenia & 140 & 15.7 \\
& (70 adolescents; 70 parents) & $(50.0 ; 50.0)$ \\
\hline Turkey & 139 & 15.6 \\
& (70 adolescents; 69 parents) & $(50.4 ; 49.6)$ \\
\hline Total & 889 & 100.0 \\
& (446 adolescents; 443 parents) & $(50.2 ; 49.8)$ \\
\hline
\end{tabular}

Due to between countries comparisons, school level was operationalized through the international classification ISCED (2012; 2014), proposed by UNESCO2. Adolescents participating in this study were

2 This classification divides the levels of formal education in nine categories, from 0 (early childhood education/no formal education) to 8 (Doctoral education or equivalent). For information, please see: http://www.uis.unesco.org/Education/Documents/isced-2011operational-manual.pdf (2012) and http://www.uis.unesco.org/Education/Documents/iscedfields-of-education-training-2013.pdf (2014). 
students from secondary education (one missing value): 54 (12.1\%) were attending ISCED level 2 (Lower secondary education); 391 (87.9\%) were attending ISCED level 3 (Upper secondary education). In the case of parents, the variation was higher as expected (11 missing values): 27 (6.2\%) from ISCED level 1 (Primary Education); 42 (9.7\%) from ISCED level 2 (Lower secondary education); 175 (40.3\%) from ISCED level 3 (Upper secondary education); 33 (7.6\%) from ISCED level 4 (Post-secondary non-tertiary education); 22 (5.1\%) from ISCED level 5 (Short-cycle tertiary education); 99 (22.8\%) from ISCED level 6 (Bachelor's or equivalent level); and 34 (7.8\%) from ISCED level 7 (Master's or equivalent level). No other sociodemographic variables were considered.

\section{Instrument development}

The Family Community and School 3 Values Questionnaire (FCS3VQ) is a self-response questionnaire that was developed by the research team to collect data about parents' and students' opinions about the importance of several values to family life and to the development of a sense of belonging to society as a citizen, autonomously and critically participating in it. It is composed by 36 items constructed according to a five-point Likert scale, from (1) Strongly Disagree to (5) Strongly Agree, and asked participants to express the degree of their agreement with sentences belonging to six defined groups of items. Each of the groups included six different aspects of previously defined conceptual clusters: (1) General active citizenship; (2) Family; (3) Health and sexuality; (4) Respect for others including intercultural diversity issues; (5) Technology and environment; (6) Work and School Ethics.

The first conceptual group (General active citizenship) includes items related to universal values like honesty, respect for others, tolerance, selfrespect, equal rights, dignity, freedom, solidarity, diversity, justice and democracy; the second (Family) involves parental perception of guidance, shared time in the family, generation gap effects, transmission of cultural heritage, and parental role models; the third (Health and sexuality) includes items related to the perception of the importance of a healthy lifestyle, the discussion of issues related to sexuality and the promotion of critical autonomy in dealing with information; the fourth (Interpersonal and intercultural diversity) contains items related to acknowledging and embracing diversity, different lifestyles and cultural heritage of groups; the fifth (Technology and environment) includes items related to promoting sustainable development and raising awareness of technology and its impacts on the planet and society, either at a global or an individual level; and the last category (Work and school ethics) aggregates items related to ethical behaviour in the main public spheres of action, such as school and 
workplace, financial issues, and social responsibility. The process of questionnaire development was rather complex and challenging because it involved all the team members participating in a five-day workshop in Portugal (March, 2015). The purpose was to decide what kind of values should be included, how they can be conceptually grouped, the phrasing of items initially in English - considering the fact that the questionnaire should than be translated into seven languages for data collection in each country, and the meaning of sentences should be the same for every participant - the type of answer scale, and the logistic and ethical issues involved in data collection.

After a brainstorming activity that consisted of listing all the values considered important for individual and interpersonal relations in the family, school and community, the team of each country agreed upon joining the 33 originally identified values in six conceptual groups or clusters. The next step was to name each group with a general term and then conceptually define the main ideas gathered in each of the six categories of values. The final step was to write sentences related to the defence of specific principles that rule behaviours which are valorized in family context. These were to be presented to the sample participants, asking them to indicate how much they agree with them considering their family ethics. From a set of 53 initial items, all the partners agreed on choosing the best six sentences of each category, with the final version of FCS3VQ having 36 items3. It was a criterion for the team not to develop an overlong instrument that could be tedious and time-consuming to fill in, especially for adolescents and parents with lower literacy rates. Due to cultural, religious and political issues (including legal frameworks) specific to each partner country, it was consensual that some matters would be excluded from the questionnaire, the final version of which would be the same for parents and adolescents in all countries, avoiding potential negative reactions, misinterpretations and missing responses. Among such issues some examples can be mentioned, such as alcohol consumption, same sex marriages, more private aspects of sexual intimacy, and the value of intergeneration learning of cultural traditions.

The initial version of the instrument was submitted in each country for translation to the corresponding language and for a pilot study with few volunteer parents and students. Following the advice of authors such as George, Faan, Pinilla, Abbound, Shea and Rand (2013), this pilot study was

\footnotetext{
3Examples of items include: "Spending time together as a family is essential" (item 1); "Working with someone who has religious principles that are different to mine is a problem in my family" (item 21; reverse-coded item); "In our family it is unacceptable to talk openly about sexuality" (item 32; reverse-coded item); "Good education is the most important thing for a person's future" (item 34).
} 
used to do a cognitive debriefing through interviewing techniques with the participants and to refine the final version of the items, allowing the identification and clarification of problematic words, unclear meanings, confounding terms and doubts about the response scale. This preliminary work was crucial to refining the final version of the instrument that was consensual for all researchers in the team.

Because the overall goal of the instrument was connected to perceptions about values that the family promotes in the process of learning and exercise citizenship, a separate question was included at the end inviting participants to indicate how they evaluate themselves as models of citizenship for others, from (1) Very Unsatisfied to (5) Very Satisfied. The questionnaire took about 15 minutes to answer.

\section{Procedures of data collection}

Following ethical codes in each country about conducting scientific research with minors, the team of each school was responsible for contacting the national entities required in such a process. They then contacted the families of students, asking for written consent from parents/tutors prepared by the research team and equal in all countries - allowing data collection with their adolescent sons and daughters. In the case of parents/tutors and in order to prevent potential error factors4, they were the first to answer the self-report questionnaire after their volunteering consent, mainly in schools during regular parents' meetings, ensuring anonymity and confidentiality of responses. Only after the administration of the instrument to mothers and fathers (or equivalent figures in terms of the responsibilities to school), were adolescents whose parents/tutors had given permission for their participation in data collection asked to answer the same instrument during class time with the support of teachers, with the same ethical guarantees.

\section{Results}

This section will be divided into subsections due to the amount of information and the need to make comparisons within and between countries. Beginning with the psychometric properties of the instrument (FCS3VQ), we then analyse results by country and between countries comparing the degree of agreement with values of adolescents and parents through the calculations of analysis of variance (ANOVA). Age and schooling level of parents were not significantly correlated with the results on the questionnaire $(r=.008$;

4 Among these potential error factors is the possibility that adolescents may inform parents about the content of the questions; they may help parents to answer the questionnaire if the instrument was taken home; parents and adolescents may agree on the opinions expressed about values. 
$\mathrm{p}=.878$ ) and with self-evaluations of citizenship ( $\mathrm{r}=-.037 ; \mathrm{p}=.451)$. The very unequal distribution of parents by schooling level categories (ISCED levels) made any possible use of this variable weak for data analyses. Thus, the two variables of age and schooling level of parents were only considered for sample description. For adolescents these two variables were controlled because they were from the same school level in each country and data were collected in the same period of the school year.

Each country's data will appear by alphabetic order of the countries' names. The possible differences in subsamples size across comparisons with numbers presented in Tables 1 and 2 are due to missing values, which were not replaced in order to respect the original data.

\section{Internal consistency indicators of the questionnaire}

In Table 3, Cronbach's alfa indicators for each scale are presented as well as for the total scale. For the entire scale internal consistency was equal to .835 when considering all the subjects, and .785 for the subgroup of adolescents and .808 for the subgroup of parents. These are very satisfactory psychometric indicators.

Table 3. Internal consistency of subscales and of total questionnaire

\begin{tabular}{|l|l|}
\hline FCS3 VQ & Cronbach's Alfa \\
\hline Subscale 1 (General active citizenship) $=6$ items & .421 \\
\hline Subscale 2 (Family) =6 items & .683 \\
\hline Subscale 3 (Health and sexuality) =6 items & .524 \\
\hline Subscale 4 (Interpersonal and intercultural diversity) =6 items & .512 \\
\hline Subscale 5 (Technology and environment) =6 items & .501 \\
\hline Subscale 6 (Work and school ethics) =6 items & .396 \\
\hline Total questionnaire (global sample) = 36 items & $\mathbf{. 8 3 5}$ \\
\hline Total questionnaire (sample of adolescents) = 36 items & $\mathbf{. 7 8 5}$ \\
\hline Total questionnaire (sample of parents) = 36 items & $\mathbf{. 8 0 8}$ \\
\hline
\end{tabular}

As it is possible to confirm in Table 3, the conceptual division of items from the questionnaire in six groups wasn't authorized by statistical analyses of internal consistency of the subscales, because the values of Cronbach's alfa were too poor to permit the use of the subscale results separately for interpretation purposes. So, it was only possible to go further on data analyses using the global result of the questionnaire, either for the total sample, or for parents and adolescents considered independently.

\section{Data from Austria}

In table 4 it is possible to explore data from the total sample and the subgroups from Austria in the answers to the values questionnaire. 
Table 4. Results in FCS3VQ from Austria

\begin{tabular}{|l|l|l|l|l|l|l|}
\hline Within country comparisons & Subgroups & $n$ & Mean & SD & $F$ & $p$ \\
\hline Comparison between fathers & Fathers & 14 & 141.79 & 23.972 & 1.148 & .289 \\
and mothers & Mothers & 43 & 147.61 & 15.169 & & \\
\hline Comparison between boys and & Boys & 40 & 132.58 & 10.539 & 1.323 & .254 \\
girls between & Girls & 30 & 129.37 & 12.781 & & \\
\hline Comparisons & Adolescents & 70 & 131.20 & 11.575 & 32.940 & $\mathbf{. 0 0 0}$ \\
adolescents and parents & Parents & 57 & 146.18 & 17.674 & & \\
\hline $\begin{array}{l}\text { Comparisons between males } \\
\text { and females }\end{array}$ & Males & 54 & 134.96 & 15.468 & 3.118 & .080 \\
\hline
\end{tabular}

In the sample of Austria parents tend to agree more than adolescents about the importance of values for the family $[F(1,125)=32.940 ; p<.001]$, and there are no other significant differences between subgroups compared.

\section{Data from Belgium}

Table 5 presents data from the sample of Belgium.

Table 5. Results in FCS3VQ from Belgium

\begin{tabular}{|l|l|l|l|l|l|l|}
\hline Within country comparisons & Subgroups & $n$ & Mean & SD & $F$ & $p$ \\
\hline Comparison between fathers & Fathers & 17 & 139.65 & 15.803 & 2.676 & .107 \\
and mothers & Mothers & 43 & 146.09 & 12.889 & & \\
\hline Comparison between boys & Boys & 22 & 130.86 & 10.139 & .539 & .466 \\
and girls & Girls & 38 & 133.18 & 12.647 & & \\
\hline Comparisons between & Adolescents & 60 & 132.33 & 11.754 & 25.679 & $\mathbf{. 0 0 0}$ \\
adolescents and parents & Parents & 60 & 144.27 & 13.949 & & \\
\hline Comparisons between males & Males & 39 & 134.69 & 13.470 & 3.833 & .053 \\
and females & Females & 81 & 140.04 & 14.255 & & \\
\hline
\end{tabular}

As happened with Austria's sample, in the participants of Belgium it was also possible to detect a statistically significant difference about the opinions of adolescents and parents, with parents again the group that tend to agree more with the importance of values to family life $[F(1,118)=25.679$; $\mathrm{p}<.001]$.There were no other differences between groups.

\section{Data from Greece}

Data from Greece are shown in Table 6.

Table 6. Results in FCS3VQ from Greece

\begin{tabular}{|l|l|l|l|l|l|l|}
\hline Within country comparisons & Subgroups & $n$ & Mean & SD & $F$ & $p$ \\
\hline Comparison between fathers & Fathers & 15 & 161.20 & 11.07 & .608 & .439 \\
and mothers & Mothers & 37 & 157.27 & 18.13 & & \\
\hline Comparison between boys and & Boys & 32 & 139.91 & 12.496 & .044 & .835 \\
girls between & Girls & 20 & 139.15 & 13.003 & & \\
\hline Comparisons & Adolescents & 52 & 139.62 & 12.572 & 42.993 & .000 \\
adolescents and parents & Parents & 52 & 158.40 & 16.399 & & \\
\hline Comparisons between males & Males & 47 & 146.70 & 15.594 & 1.527 & .219 \\
and females & Females & 57 & 150.91 & 18.570 & & \\
\hline
\end{tabular}


Also in Greece, parents $[\mathrm{F}(1,102)=42.993 ; \mathrm{p}<.001]$ tended to score higher than adolescents when evaluating the significance of values for family members. There were no other differences between groups.

\section{Data from Portugal}

Data from Portugal are shown in Table 7. The first comparison was not calculated for this sample because of the reduced number of fathers who agreed to answer the questionnaire.

Table 7. Results in FCS3VQ from Portugal

\begin{tabular}{|l|l|l|l|l|l|l|}
\hline Within country comparisons & Subgroups & $n$ & Mean & SD & $F$ & $p$ \\
\hline $\begin{array}{l}\text { Comparison between fathers } \\
\text { and mothers }\end{array}$ & Fathers & 7 & 158.43 & 9.947 & --- & --- \\
\hline $\begin{array}{l}\text { Comparison between boys } \\
\text { and girls }\end{array}$ & Boysers & 37 & 158.62 & 10.523 & & \\
\hline Comparisons between & Girls & 21 & 142.71 & 13.473 & .777 & .383 \\
adolescents and parents & Adolescents & 49 & 146.07 & 12.809 & & \\
\hline $\begin{array}{l}\text { Comparisons between males } \\
\text { and females }\end{array}$ & Males & 44 & 158.59 & 12.957 & 32.142 & $\mathbf{. 0 0 0}$ \\
\hline
\end{tabular}

Note: In the case of Portugal the number of fathers did not allow valid statistical comparisons.

In the Portuguese sample there are two significant differences that could be interpreted. Again, as in previously analyzed countries, parents tend to agree more than adolescents $[F(1,91)=32.142 ; \mathrm{p}<.001]$ about the importance of values for their family. When males (fathers and boys) are compared to females (mothers and girls), this second group scored higher than the first $[\mathrm{F}(1,90)=4.827 ; \mathrm{p}=.031]$, which means that females of the sample tend to consent more than males on the significance of values for their family principles.

\section{Data from Romania}

It is possible to see the results from Romania in Table 8. In this sample there are three statistically significant differences between groups.

Table 8. Results in FCS3VQ from Romania

\begin{tabular}{|l|l|l|l|l|l|l|}
\hline Within country comparisons & Subgroups & $n$ & Mean & SD & $F$ & $p$ \\
\hline $\begin{array}{l}\text { Comparison between fathers } \\
\text { and mothers }\end{array}$ & Fathers & 15 & 138.47 & 7.900 & .344 & .559 \\
\hline Comparison between boys & Mothers & 69 & 140.20 & 10.662 & & \\
and girls & Boys & 28 & 128.50 & 10.571 & 5.875 & $\mathbf{. 0 1 8}$ \\
\hline Comparisons between & Girls & 41 & 134.39 & 9.442 & & \\
adolescents and parents & Parents & 69 & 132.00 & 10.261 & 20.390 & $\mathbf{. 0 0 0}$ \\
\hline Comparisons between males & Males & 43 & 139.83 & 10.098 & & \\
and females & Females & 95 & 137.69 & 10.76 & 8.637 & $\mathbf{. 0 0 4}$ \\
\hline
\end{tabular}

Adolescent Romanian girls tend to agree more than boys on the importance of values for family life $[F(1,67)=5.785 ; p=.018]$; parents scored 
higher than adolescents $[\mathrm{F}(1,136)=20.390 ; \mathrm{p}<.001]$ on FCS3VQ; and females of the sample tend to consider values as more significant than males $[F(1,136)=8.637 ; \mathrm{p}=.004]$ as rules for family conduct.

\section{Data from Slovenia}

Data from Slovenia can be examined in Table 9.

Table 9. Results in FCS3VQ from Slovenia

\begin{tabular}{|l|l|l|l|l|l|l|}
\hline Within country comparisons & Subgroups & $n$ & Mean & SD & $F$ & $p$ \\
\hline Comparison between fathers & Fathers & 25 & 149.84 & 13.322 & 2.306 & .134 \\
and mothers & Mothers & 45 & 154.13 & 10.087 & & \\
\hline Comparison between boys & Boys & 36 & 127.97 & 12.192 & .826 & .367 \\
and girls & Girls & 34 & 130.82 & 14.033 & & \\
\hline Comparisons between & Adolescents & 70 & 129.36 & 13.101 & 124.986 & $\mathbf{. 0 0 0}$ \\
adolescents and parents & Parents & 70 & 152.60 & 11.442 & & \\
\hline Comparisons between males & Males & 61 & 136.93 & 16.592 & 6.418 & $\mathbf{. 0 1 2}$ \\
and females & Females & 79 & 144.10 & 16.602 & & \\
\hline
\end{tabular}

In this sample parents also tend to agree more on the importance of values than adolescents $[\mathrm{F}(1,138)=124.986 ; \mathrm{p}<.001]$, and as in Romanian and Portuguese samples, females also tend to score higher than males in their opinions on the questionnaire $[\mathrm{F}(1,138)=6.418 ; \mathrm{p}=.012]$, thus considering values more important for guiding family life.

\section{Data from Turkey}

Data from Turkey appear in Table 10 and the comparison between fathers and mothers shows an interesting result not observed in other countries.

Table 10. Results in FCS3VQ from Turkey

\begin{tabular}{|l|l|c|l|l|l|l|}
\hline Within country comparisons & Subgroups & $n$ & Mean & SD & $F$ & $p$ \\
\hline Comparison between fathers & Fathers & 27 & 145.00 & 12.866 & 11.669 & $\mathbf{. 0 0 1}$ \\
and mothers & Mothers & 29 & 155.34 & 9.674 & & \\
\hline $\begin{array}{l}\text { Comparison between boys and } \\
\text { girls between }\end{array}$ & Goys & 22 & 142.41 & 14.861 & 1.461 & .232 \\
\hline Comparisons bolescents & 30 & 146.70 & 10.764 & & \\
adolescents and parents & Parents & 56 & 144.60 & 12.747 & 5.717 & $\mathbf{. 0 1 9}$ \\
\hline $\begin{array}{l}\text { Comparisons between males } \\
\text { and females }\end{array}$ & Males & 49 & 143.84 & 12.374 & & \\
\hline
\end{tabular}

In the Turkish sample, mothers agreed more than fathers about the importance of values to family life $[\mathrm{F}(1,54)=11.669$; $\mathrm{p}=.001]$; there are differences between adolescents and parents, as in other samples, with the latter scoring higher than the former $[\mathrm{F}(1,107)=5.717 ; \mathrm{p}=.019]$; and there are statistically significant differences in the answers of males and females $[F(1$, 106) $=8.912 ; \mathrm{p}=.004]$, women being more likely to agree about the importance of values for family life than men. 


\section{Between country comparisons}

The comparisons between seven countries were made contrasting data from the same groups as was done for within country analyses: mothers vs. fathers; boys vs. girls; adolescents vs. parents; males vs. females. The results obtained are shown in Table 10.

Table 10. Results in FCS3VQ by subgroups - all countries considered

\begin{tabular}{|l|l|l|l|l|l|l|}
\hline Between countries comparisons & Subgroups & $n$ & Mean & SD & $F$ & $p$ \\
\hline $\begin{array}{l}\text { Comparison between fathers } \\
\text { and mothers }\end{array}$ & Fathers & 120 & 146.87 & 15.838 & 5.025 & $\mathbf{. 0 2 6}$ \\
\hline $\begin{array}{l}\text { Comparison between boys and } \\
\text { girls }\end{array}$ & Mothers & 288 & 150.45 & 14.206 & & \\
\hline $\begin{array}{l}\text { Comparisons } \\
\text { adolescents and parents between }\end{array}$ & Girls & 201 & 134.30 & 13.138 & 2.819 & .094 \\
\hline $\begin{array}{l}\text { Comparisons between males } \\
\text { and females }\end{array}$ & Parents & 423 & 136.49 & 13.602 & & \\
\hline
\end{tabular}

With the exception of adolescents of both sexes, there are significant differences in answers of other groups, when all countries are considered together. Mothers tend to agree more than fathers $[\mathrm{F}(1,406)=5.025 ; \mathrm{p}=.026]$ about the importance of values for the family; parents scored higher than adolescents $[\mathrm{F}(1,829)=202.890 ; \mathrm{p}<.001]$; and females displayed a higher degree of agreement with the sentences about family values promotion than males $[\mathrm{F}(1,827)=23.900 ; \mathrm{p}<.001]$.

The results of all countries cross comparison in the total score of FCS3VQ are described in Table 11. Because the test of analysis of variance permits only a global comparison, post hoc tests (Vogt, 1993) were then performed to detect differences between specific countries.

Table 11. Differences in FCS3VQ global score between countries

\begin{tabular}{|c|c|c|c|c|c|}
\hline Countries & $n$ & Mean & $S D$ & $F$ & $p$ \\
\hline Austria & 127 & 137.92 & 16.374 & \multirow{7}{*}{19.452} & \multirow{7}{*}{.000} \\
\hline Belgium & 120 & 138.30 & 14.173 & & \\
\hline Greece & 104 & 149.01 & 17.335 & & \\
\hline Portugal & 93 & 151.28 & 13.635 & & \\
\hline Romania & 138 & 135.91 & 10.877 & & \\
\hline Slovenia & 140 & 140.98 & 16.918 & & \\
\hline Turkey & 109 & 147.56 & 12.828 & & \\
\hline
\end{tabular}

Note: Post hoc comparisons were than calculated.

Using the Scheffe test of multiple comparisons, it was possible to find that Austria had a significantly lower result at $\mathrm{p}<.001$ on the questionnaire than Portugal, Greece and Turkey, not differing from the other countries. Also, for Belgian participants the degree of agreement about the importance of values for family measured by FCS3VQ was lower than for subjects from Greece $(\mathrm{p}<.001)$, Portugal $(\mathrm{p}<.001)$, and Turkey $(\mathrm{p}=.001)$, which tend to consider such values more important for family life. In the 
case of Greece, apart from its aforementioned differences in scores with Austria and Belgium (Greek participants scored higher than Austrians and Belgians), the results also show that Greeks agreed more than participants from Romania $(p<.001)$ and Slovenia $(p=.008)$ about the significance of values to family life. The Portuguese sample scored higher, at $\mathrm{p}<.001$, on its agreement with values than participants from Austria, Belgium, Romania, and Slovenia. Romanian participants scored significantly lower than those from Greece, Portugal and Turkey. Slovenian participants scored lower than subjects from Greece $(p=.008)$ and Portugal $(p<.001)$. Finally, respondents from Turkey demonstrated a higher degree of agreement with values for the family than participants of Austria $(\mathrm{p}<.001)$, Belgium $(\mathrm{p}=.001)$, and Romania $(\mathrm{p}<.001)$.

Table 12. Results in self-evaluations of citizenship comparing adolescents and parents in each country

\begin{tabular}{|c|c|c|c|c|c|c|}
\hline Countries & Subgroups & $n$ & Mean & $S D$ & $F$ & $p$ \\
\hline Austria & $\begin{array}{l}\text { Adolescents } \\
\text { Parents }\end{array}$ & $\begin{array}{l}70 \\
59 \\
\end{array}$ & $\begin{array}{l}3.43 \\
3.71 \\
\end{array}$ & $\begin{array}{l}.827 \\
.929 \\
\end{array}$ & 3.356 & .069 \\
\hline Belgium & $\begin{array}{l}\text { Adolescents } \\
\text { Parents }\end{array}$ & $\begin{array}{l}60 \\
60 \\
\end{array}$ & $\begin{array}{l}3.53 \\
3.98 \\
\end{array}$ & $\begin{array}{l}.929 \\
.676 \\
\end{array}$ & 9.200 & .003 \\
\hline Greece & $\begin{array}{l}\text { Adolescents } \\
\text { Parents }\end{array}$ & $\begin{array}{l}52 \\
52 \\
\end{array}$ & $\begin{array}{l}3.85 \\
3.65 \\
\end{array}$ & $\begin{array}{l}.697 \\
.988 \\
\end{array}$ & 1.316 & .254 \\
\hline Portugal & $\begin{array}{l}\text { Adolescents } \\
\text { Parents }\end{array}$ & $\begin{array}{l}51 \\
48\end{array}$ & $\begin{array}{l}4.18 \\
4.13\end{array}$ & $\begin{array}{l}.590 \\
.733\end{array}$ & .149 & .700 \\
\hline Romania & $\begin{array}{l}\text { Adolescents } \\
\text { Parents }\end{array}$ & $\begin{array}{l}69 \\
69\end{array}$ & $\begin{array}{l}3.71 \\
3.96\end{array}$ & .621 & 5.804 & .017 \\
\hline Slovenia & $\begin{array}{l}\text { Adolescents } \\
\text { Parents }\end{array}$ & $\begin{array}{l}70 \\
69 \\
\end{array}$ & $\begin{array}{l}3.46 \\
2.68 \\
\end{array}$ & $\begin{array}{l}.912 \\
.849 \\
\end{array}$ & 26.952 & .000 \\
\hline Turkey & $\begin{array}{l}\text { Adolescents } \\
\text { Parents }\end{array}$ & $\begin{array}{l}63 \\
64 \\
\end{array}$ & $\begin{array}{l}3.98 \\
4.14 \\
\end{array}$ & $\begin{array}{l}.852 \\
.794 \\
\end{array}$ & 1.147 & .286 \\
\hline
\end{tabular}

The responses to the separate question that invited participants to do a self-evaluation as 'models of citizenship' (model citizens) to others are systematized in Table 12, which compares adolescents' and parents' opinions in each country. There are no differences between the two generations in Austria, Greece, Portugal, and Turkey. In Belgium [F(1, $118=9.200 ; \mathrm{p}=.003]$ and Romania $[\mathrm{F}(1,136)=5.804 ; \mathrm{p}=.017]$, parents tend to evaluate themselves better than adolescents in the exercise of citizenship duties and responsibilities. In Slovenia $[F(1,137)=26.952 ; \mathrm{p}<.001]$ the opposite was observed, with youngsters being those who scored higher than parents in this variable.

The results of a global comparison between countries are described in Table 13. Again, post hoc tests were further executed to detect between which countries' differences are statistically interpretable. 
Table 13. Differences in self-evaluations of citizenship between countries

\begin{tabular}{|c|c|c|c|c|c|}
\hline Countries & $n$ & Mean & $S D$ & $F$ & $p$ \\
\hline Austria & 129 & 3.56 & .883 & \multirow{7}{*}{24.294} & \multirow{7}{*}{.000} \\
\hline Belgium & 120 & 3.76 & .840 & & \\
\hline Greece & 104 & 3.75 & .856 & & \\
\hline Portugal & 99 & 4.15 & .660 & & \\
\hline Romania & 138 & 3.83 & .611 & & \\
\hline Slovenia & 139 & 3.07 & .960 & & \\
\hline Turkey & 127 & 4.06 & .824 & & \\
\hline
\end{tabular}

Note: Post hoc comparisons were than calculated.

In self-evaluation of citizenship performance, participants from Austria scored lower than those from Portugal $(\mathrm{p}<.001)$ and Turkey $(p<.001)$, and significantly higher than subjects from Slovenia $(p=.001)$; Belgian respondents only differ from those of Slovenia, scoring higher than them $(\mathrm{p}<.001)$ in their self-perceptions; Greek participants scored higher than Slovenian ones $(\mathrm{p}<.001)$; for Portugal the scores were higher at $\mathrm{p}<.001$ than those from Austria and Slovenia; the results from the Romanian sample were higher than only those from Slovenia; this country seems to be the one which had the lowest results in self-evaluations, differing significantly from all the other countries ( $\mathrm{p}=.001$ for the comparison with Austria; $\mathrm{p}<.001$ for the comparison with Belgium, Greece, Portugal, Romania, and Turkey); Turkey displayed significantly higher results on self-evaluations than Austria $(p<.001)$ and Slovenia $(p<.001)$. These differences between countries are surprising and the influences on responses could be multiple, considering the fact an abstract and general concept of citizenship is involved, and that this item was one of the most difficult to write due to the inexistence of a term in each language that allows an equivalent translation of citizenship.

\section{Discussion}

In all countries that entered in the study, parents tended to evaluate the transmission and cohesion of values in the family context more favourably than adolescents, because they agreed more than the youngsters about the importance of values for family life. Because of weak psychometric internal consistency indicators of each subscale it is not possible to deepen these data analyses, trying to search for greater differences between two generations in specific sets of values. Probably it will be possible with an exploratory factorial analysis of answers, which will be a challenging task in the near future for the research team. Also, with the exception of Austria, Belgium, and Greece, where there is no differences between the two sexes, in other countries such as Portugal, Romania, Slovenia and Turkey, mothers and adolescent girls (as a group) tend to 
evaluate values as more important for family principles than fathers and adolescent boys (considered together as a group).

Some unique results of countries, such as the difference in opinions between Romanian girls and boys about the importance of values for the family (female adolescents scored higher than their male counter partners), or the higher agreement of mothers from Turkey when compared to fathers also about the defence of values as principles for the family, could be explained by cultural and religious factors, including traditional gender roles (Vieira, Nogueira \& Tavares, 2013; Derks \& Ellemeres, 2016), daily routines and responsibilities of family members, composition of family and economic conditions, among other aspects. This could be also true to explain why in countries like Austria, Belgium and Greece, there were no differences between males and females in their agreement about the importance of values, which didn't happen in the samples from Portugal, Romania, Slovenia, and Turkey. In these four latter countries, females tend to agree more than males about the importance of values.

This project intended to make a 'healthy', educative and heuristic comparison of answers of parents and adolescents of the same age, from seven countries, in a questionnaire that asked participants to express their degree of agreement about how important values are for family life. The goal of the study was not to do a ranking of countries or to generalize data and such unwelcome pretensions weren't possible due to the reduced number of participants in each country, the nature of the study and the several error factors unavoidably involved. In fact, results should be interpreted with limitations because of methodological weaknesses that are common in such large-scale comparisons using non-experimental strategies. The translation of the questionnaire from English to the seven languages was a potential threat to internal validity of answers because of specific concepts (like citizenship) and phrasing (Social Security, as a State entity). Other factors that may cause some interference in results are related to participants' family socioeconomic status, the location of schools in each country (more rural or more urban zones), the (lack of) familiarization of parents with this type of surveys or the importance they give to collaborating with school demands, just to name a few.

Overall, these results call attention to the differences in parents' and adolescents' perceptions about the relative importance of values for family life. Parents in all seven countries are more convinced than adolescents that such core values are important and promoted in their families, which may reveal a possible incongruence between parents' beliefs and practices in the family context, less time available than is desirable for communication between parents and children, or a lack of reflection from adolescents about 
such values for their life, probably due to age and all the transformations and requirements of adolescence as a developmental stage.

According to Sprinthall and Collins (1994), "the maxim that growth depends upon interaction holds for value development just as surely as it holds for all other forms of development” (p. 214). This calls for the importance of having time in a family context - and also at school and other educational contexts - to create situations to discuss values, to help children and adolescents to progressively acquire the ability to understand the diversity of human beings not as a problem but as a richness for mutual relationships. Also such opportunities may be seen as valuable moments to foster awareness both in the youth and in educators (e.g., parents, teachers) about the complexities, challenges, and advantages for all of living together as equals in culturally diverse democratic societies5.

\section{References:}

Braithwaite, V. A., \& Law, H. G. (1985). Structure of human values: Testing the adequacy of the Rokeach Value Survey. Journal of Psychology and Social Psychology, 49(1), 250-263. doi http://dx.doi.org/10.1037/00223514.49.1.250

Bugental, D. B., \& Johnston, C. (2000). Parental and child cognitions in the context of the family. Annual Review of Psychology, 51, 315-344. doi: 10.1146/annurev.psych.51.1.315

European Commission (2016). Promoting citizenship and the common values of freedom, tolerance and non-discrimination through education. Luxembourg: Publications Office of the European Union. Retrieved from https://webgate.ec.europa.eu/fpfis/mwikis/eurydice/images/1/14/Leaflet_Pari s_Declaration.pdf

European Council (2016). Competences for democratic culture. Living together as equals in culturally diverse democratic societies. Retrieved from http://www.coe.int/t/dg4/education/Source/competences/CDC_en.pdf

Derks, B., \& Ellemers, N. (2016). Gender and social hierarchies. Introduction and overview. In K. Faniko, F. Lorenzi-Cioldi, O. Sarrasin, \& E. Mayor (Eds.), Gender and social hierarchies. Perspectives from social psychology (pp. 1-7). London: Routledge.

DGE (2013). Citizenship education. Guidelines. Lisbon: Directive Board of Education. Retrieved from http://dge.mec.pt/sites/default/files/ECidadania/citizenship_education_guidel ines.pdf

5 This is the second title of a publication of European Council (2016), Competences for democratic societies. Living together as equals in diverse democratic societies. Retrieved from: http://www.coe.int/t/dg4/education/Source/competences/CDC_en.pdf 
George, M., Pinilla, R., Abboud, S., Shea, J., \& Rand, C., (2013). Innovative use of a standardized debriefing guide to assist in the development of a research questionnaire with low literacy demands. Applied Nursing Research, 26, 139-42. doi: http://dx.doi.org/10.1016/j.apnr.2012.11.005 Goodnow, J. J., \& Collins, W. A. (1990). Development according to parents: The nature, sources, and consequences of parents' ideas. Hillsdale, NJ: Lawrence Erlbaum Associates.

Jacklin, C. N., \& Reynolds, C. (1993). Gender and childhood socialization. In A. E. Beall, \& R. J. Sternberg (Eds.). The psychology of gender (pp. 197214). New York: Guilford Press.

Jagland, T. (2016). Preface. In European Council (Ed.), Competences for democratic culture. Living together as equals in culturally diverse democratic societies (pp. 6-7). Retrieved from http://www.coe.int/t/dg4/education/Source/competences/CDC_en.pdf McGillicuddy-De Lisi, A. V., \& Sigel, I. E. (1995). Parental beliefs. In M. H. Bornstein (Ed.), Handbook of Parenting. Vol. 3: Status and Social Conditions of Parenting (pp. 333-358). New Jersey: Lawrence Erlbaum Associates, Publishers.

Rokeach, M. (1973). The nature of human values. New York: The Free Press.

Sprinthall, N., \& Collins, W. A. (1994). Adolescent Psychology. A developmental view ( $2^{\text {nd }}$ ed.). New York: McGraw-Hill Company.

UNESCO (2012). International Standard Classification of Education ISCED 2011. Canada: UNESCO Institute for Statistics. Retrieved from http://www.uis.unesco.org/Education/Documents/isced-2011-operationalmanual.pdf

UNESCO (2014). ISCED Fields of Education and Training 2013 (ISCED-F 2013). Manual to accompany the International Standard Classification of Education 2011. Canada: UNESCO Institute for Statistics. Retrieved from http://www.uis.unesco.org/Education/Documents/isced-fields-of-educationtraining-2013.pdf

Vieira, C. C. (Coord.), Nogueira, C. \& Tavares, T.-C. (2013). Theoretical Framework. In T. Pinto (Coord.), C. Nogueira, C. C. Vieira, I. Silva, L. Saavedra, M. J. Silva, P. Silva, T.-C. Tavares \& V. Prazeres (Eds.), Education Guide. Gender and Citizenship 3rd Cycle (pp. 13-46). Lisbon: Commission for Citizenship and Gender Equality. Retrieved from https://www.cig.gov.pt/pdf/2014/Education_Guide_3rd_Cicle.pdf Vieira, C. C. (2013). Educação Familiar. Estratégia para a promoção da igualdade de Género ( $3^{\mathrm{a}}$ ed.). Lisboa: Comissão para a Cidadania e Igualdade de Género. Retrieved from https://infoeuropa.eurocid.pt/registo/000043757/ 